\title{
PROJECT METHOD AS A NEW PERSONALITY-ORIENTED TECHNOLOGY OF TEACHING FOREIGN LANGUAGES IN TECHNICAL UNIVERSITIES
}

\author{
Voronova Ye. M. \\ Kharkiv National Automobile and Highway University
}

\begin{abstract}
The article emphasizes that one of the most organic and effective forms of independent learning by students while learning a foreign language is the project method. The novelty of the project method as a relatively new method of teaching foreign languages, which is a personality-oriented technology, is shown.

The project method is now very actual because, as a relatively new method in teaching foreign languages, it actively involves students in various practical activities and allows them to develop their creative and individual abilities.

The project method is one of the methods of developing communicative competence in the study of English by students of technical universities.

The use of the method of educational projects in pedagogical work is determined by the need to form a person of the XXI century, a person of a new era, when the determining factors in the development of society are human intelligence and information. It is shown that the project method is one of the methods of developing communicative competence in learning English by students of technical universities.
\end{abstract}

Project method as a new personality - oriented technology of teaching foreign languages - in technical universities. The main purpose of the project method is to provide students with the opportunity to acquire independently knowledge in the process of solving practical problems or problems that require the integration of knowledge from different subject areas. The role of the teacher is a coordinator, an expert, a certain source of additional information.

Unlike other technologies, the project method makes it possible to involve students in real communication, full of foreign language contacts, it is a method of achieving a specific (methodical) goal by researching the problem and getting a really practical result, namely the development of communicative competence of future professionals.

The article shows the differences between teaching by traditional methods and when learning with the help of the project method.

The project method is an alternative to the traditional approach to education, which is based mainly on the acquisition of ready knowledge and their perception.

The project methodology shifts the emphasis from different types of exercises to active mental activity of students who need skillful mastery of certain language tools.

Key words: acquiring knowledge, method, novelty, personality -oriented, technology communicative competence.

\section{Introduction}

Many researchers believe that the acquired knowledge changes every year, so it is important that young people be able to think independently, learn, work with information, improve their knowledge and skills in various fields, acquiring, if necessary, new knowledge, professions,

Therefore, it is necessary to find new approaches to teaching a foreign language.

Using the innovative forms of education requires the influence of the teacher on the activities of each student and his involvement in active educational and practical activities.

One of the most organic and effective forms of independent acquiring knowledge by students when studying a foreign language is the project method This method is relatively new in world pedagogy, it came into existence in the 1920s in the United States, and attracted the attention of scientists in Ukraine.

The ideas of American teachers J. Dewey and H.W. Kilpatrick were further developed [1].

The project method has been actively developed in the United States, Italy Great Britain, Germany and other countries.

Using project work, students are involved in exploratory learning activities, organized by the teacher, who relies on the capabilities and abilities of students to think creatively. 
The project method is now very actual because, as a relatively new method in teaching foreign languages, it actively involves students in various practical activities and allows them to develop their creative and individual abilities. The project method is one of the methods of developing communicative competence in the study of English by students of technical universities.

The use of the method of educational projects in pedagogical work is determined by the need to form a person of the XXI century, a person of a new era, when the determining factors in the development of society are human intelligence and information.

\section{Analysis of publications}

Numerous studies found that project activity is an important component of the system of productive education and is a non-standard, nontraditional way of organizing educational processes through active methods of action (planning, forecasting, analysis, synthesis) aimed at implementing a person-centered approach.

The formation and development of skills of communicative competence of students of technical ZVO by means of a foreign language on the basis of project methodology is an IMPORTANT phenomenon it should be carried out within the concept of personality-oriented education, the content of which includes personality-semantic components considers Bajdurova Л.А [2].

Haines S. emphasizes that the development of communication skills of technical students using project methodology involves reliance on pedagogical theories of learning self-initiation and self-reliance points [3].

According to Milrud Р.П., the organization of students' work on the project methodology is a special form of educational activity [4].

Frej $\mathrm{K}$ underlines that the main purpose of teaching foreign languages - at the present stage is the student's personality, able and interested in participating in intercultural communication in the language studied, and independently improve speech activities in foreign language, which he learns [5].

\section{Purpose and Problem Description}

The main purpose of the project method is to provide students with the opportunity to acquire independently knowledge in the process of solving practical problems or problems that require the integration of knowledge from different subject areas. By the project method, we mean a comprehensive educational method that allows students to exercise independence in planning, organizing, correcting and monitoring their activities. The teacher's role is a coordinator, expert, certain source of additional information.

Unlike other technologies the project technique gives the opportunity to include students in real communication, saturated with foreign language contacts it's the method of reaching a specific (methodical) goal through researching a problem and obtaining a really practical result, namely the development of communicative competences to future specialists.

\section{The main principles of personality- oriented technology in education}

The cornerstones on which this technology rests are independence, activity, efficiency. The project method can be attributed to technologies dedicated to a personality-oriented approach in teaching a foreign language. It is widely used in many countries, since it allows to organically integrate the knowledge of students from different branches of science and technology when solving one project, allows them to apply the knowledge gained in practice, while generating new ideas. Project-based learning actively influences the motivational sphere of the student.

Work on projects:

1) allows you to enrich knowledge on the subject;

2) creates the most favorable conditions for disclosure and manifestation personal abilities of the student;

3 ) reveals his individuality, more vividly reveals the creative potential of the future specialist;

4 ) is one of the most successful forms of mastering a foreign language,

There can be identified a lot of differences in the project method in comparison with traditional one, among which the most significant are the following when project participants:

- take project initiative from anyone in life;

- agree with each other about the form of training;

- develop the project initiative and bring it to the attention of everyone;

- organize themselves for business;

- keep each other informed about the progress of affairs;

- enter into discussion

Here it can be reflected the main principles of personality-oriented technology in education:

- $\quad$ special attention to the individuality of a person, his personality; 
- clarity and focus on the conscious development of critical thinking of students.

Learning using traditional methods:

- the activity of students is clearly regulated by the plan, there are almost no problem tasks that students performed independently;

- the topic is the same for all students, regardless of interests or desires;

- students learn vocabulary in parts to get a grade in class, that is, short-term memory is triggered.

When learning using the project method:

- students have an opportunity to work on a topic that interests them;

- the topic of the project chosen by each student is interesting to him / her personally, so there is a desire to learn something new, to surprise classmates and the teacher;

- research and defense of the chosen topic encourages a meaningful study of new vocabulary, including terminology.

Thus, the project methodology is an alternative to the traditional approach to education, based mainly on the assimilation of ready-made knowledge and their perception.

The project methodology shifts the emphasis from various types of exercises to the active thinking activity of students who require skillful mastery of certain language means.

The project methodology uses all the best ideas developed by traditional and modern methods of teaching English.

These include, first of all, diversity, problematicity, learning with pleasure, and the like.

1. Diversity as a necessary feature of any learning contributes to maintaining interest in learning - this is a variety of topics, types of texts (dialogues, monologues, letters, games, descriptions, instructions, etc.), and a variety of forms of educational activity (individual, pair work, group work teamwork), and a variety of types of exercises.

2. Problematicity means that students use the language both to perform tasks that are characterized by the novelty of the result, and by new means of achieving it. Problems make you think, the student learns by thinking, reflecting. There is a wide range of communication tasks and problem-solving design work. A problematic approach takes place in teaching grammar in those cases when the student uses it in speech, and when he perceives it as a system.

3 . Learning with pleasure is of course important when a student learns with pleasure. A student learns productively and learns a lot if he learns freely, without muddiness, feeling joy. Entertainment can be one of the features of the project. Often tasks can be made out in the form of a joke, a puzzle, a riddle, etc., have musical accompaniment, noise effects, illustrations.

4. The novelty of the approach is that students are given the opportunity to design the content of communication themselves, starting from the first lesson on the project.

The signs of the project methodology as a new personality-oriented technology are:

1. The presence of the author's conceptual idea - a personal-activity approach to teaching a foreign language.

2. Accuracy and predictability of results, awareness of ways to achieve them.

3 . Focus on creating a specific speech product (dialogue, monologue, etc.), embodied in the types and forms of educational and extracurricular activities (collage, comic strip, script, diary, wall newspaper).

4. Connection of the project idea with real life: the presence of connections between theory and practice.

5. Self-organization and responsibility of the project participants. Consulting and coordinating nature of the teacher's activities.

6 . The technology of teaching communicative competence (linguistic, speech, sociocultural, compensatory, educational) has been substantiated, which is the main condition for the development of intercultural communication in general.

This technology provides for the temporal and structural completeness of the project, namely: the presence of a clear algorithm for performing sequential actions.

The project methodology implements the best ideas of traditional and modern methods of teaching foreign languages, namely:

- $\quad$ problematic (the language is used to perform tasks that are characterized by novelty and make you think)

- $\quad$ satisfaction (principle of orientation towards success)

- $\quad$ using not only verbal means of expression;

- widespread use of innovative technologies in the preparation process.

- The project method in teaching a foreign language in a non-language (technical) university is a didactic means of activating the cognitive activity of future engineers, a method of developing their creativity, which also contributes to the formation of certain personal qualities. 
- The cornerstones on which this technology is based are independence, activity, efficiency. The project method can be attributed to technologies dedicated to the personalityoriented approach in foreign language teaching.

It is widely used in many countries because it allows to integrate organically the knowledge of students from different fields of science and technology in solving a single project, to apply the knowledge in practice, while generating new ideas. It actively influences the motivational sphere of the learner.

- Work on projects:

1) allows to enrich knowledge on a subject;

2) creates the most favorable conditions for manifestation personal abilities of the student;

3 ) reveals his individuality, more clearly reveals the creative potential of the future specialist;

4) is one of the most successful forms of learning a foreign language, stimulating students' speech and mental activity and causing a lively interest and healthy passion;

5) allows to find application to individual abilities, needs, interests and desires of students;

6) promotes the unification of the student group.

The project methodology meets all the goals of foreign language education:

- allows to analyze and systematize the studied material;

- develops skills of all types of speech activity, intellectual and creative abilities of students;

- cultivates a positive and tolerant attitude to the culture of English-speaking countries and a deeper attitude to their own culture.

This method makes it possible to create a research, creative atmosphere in the room, where each student in the lecture room with any level of knowledge, skills and abilities is involved in a complex creative process.

It is clear that the latter argument is especially important for students of technical universities who study using project method.

\section{Conclusion}

Thus, the main goal of the project method is to provide students with the opportunity to acquire knowledge independently in the process of solving practical problems or problems that require the integration of knowledge from various subject areas. The teacher in the project is assigned the role of a coordinator, expert, additional source of information. By the project method, we mean a comprehensive educational method that allows students to exercise independence in planning, organizing, correcting and monitoring their activities

The project method in teaching a foreign language in a non-language (technical) university is a didactic means of activating the cognitive activity of future engineers, a method of developing their creativity, which also contributes to the formation of certain personal qualities. Therefore, speaking about the project method, we mean a way to achieve a specific didactic (methodological) goal by developing a problem and obtaining a real practical result, in our case, the development of the communicative competence of students as future specialists in engineering specialties.

When implementing the project, not only its results are valuable, but also the process itself, which allows students to feel like real future professionals in the modern conditions of transformation of educational processes in accordance with the requirements of society and the labor market

So, at the stage of developing the communicative and professional competence of technical students using project method mastering foreign languages - in technical universities is a means of obtaining new information, enriching vocabulary, expanding linguistic knowledge, and applying them in future professional activities comes.

\section{References}

1. Dewey J., Dewey E. Schools in Future. Berlin, 2015. 178 p.

2. Baidurova L.A., Shaposhnikov T.V. Method of projects in teaching students two foreign languages. Foreign. lang. at school, 2012. No. 1. p. 5-11.

3. Haines S. Project: Material for Teachers. Harlow: Longman, 2015. $212 \mathrm{p}$.

4. Milrud R.P., Maximova I.R. Modern conceptual principles of communicative teaching in foreign languages. Foreign. lang. at school, 2009. No. 4. p. 9-16.

5. Frey K. Project method. Berlin: Balz, 2016. 349 p.

Voronova Ye. M., Associate Prof., Department of Foreign Languages, tel. +380677244487 ,

e-mail. voronova1945@gmail.com.

Kharkov National Automobile and Highway University, 25, Yaroslava Mudrogo str., Kharkiv, 61002, Ukraine.

Проектний метод як нова оріснтована технологія навчання іноземних мов в технічних університетів.

Анотація. У статті підкреслюється, що однією з найбільш органічних та ефективних форм 
самостійного засвоєння знань студентами під час вивчення іноземної мови є метод проектів.

Показана новизна методу проектів як відносно нового методу навчання іноземних мов, щуо є особистісно- орієнтованою технологією.

Ключові слова: придбання знань, методика, новизна, особистісно-орієнтованість, комунікативна компетентність.

Воронова Е. М., доцент кафедри іноземних мов, тел .: +380677244487, e-mail: voronova1945@gmail.com,

Харківський національний автомобільнодорожній університет, 61002, Україна, м. Харків, вул. Ярослава Мудрого, 25.

Проектный метод как новая лично-
ориентированная технология обучения иност-
ранным языкам в технических вузах

Аннотация. В статье подчеркивается, что одной из наиболее органических и эффективных форм самостоятельного приобретения знаний студентами при изучении иностранного языка является проектный метод. Раскрывается новизна проектной методики как относительно нового метода обучения иностранным языкам, являющегося личностно-ориентированной технологией.

Ключевые слова: приобретение знаний, методи$к а$, новизна, личностно-ориентированность, коммуникативная компетентность

Воронова Е. М., доцент кафедры иностранных языков, тел.: +380677244487, e-mail: voronova1945@gmail.com,

Харківський національний автомобільнодорожній університет, 61002, Україна, м. Харків, вул. Ярослава Мудрого, 25. 